\title{
Syntactic Foams Efficiency with the Use of Various Microspheres for Heat Supply Equipment and Pipelines Heat Insulation
}

\author{
Artem Vyacheslavovich Ryzhenkov ${ }^{1}$, Sergej Ivanovich Pogorelov ${ }^{1}$, Natalia Aramovna Loginova ${ }^{1}$, Elena \\ Vladimirovna Belyaeva ${ }^{1} \&$ Anastasiya Yurjevna Plestsheva ${ }^{1}$ \\ ${ }^{1}$ National Research University "Moscow Power Engineering Institute", Moscow, Russia \\ Correspondence: Natalia Aramovna Loginova, National Research University "Moscow Power Engineering \\ Institute", Krasnokazarmennaya str., 14, Moscow, 111250, Russia.
}

Received: October 30, 2014

doi:10.5539/mas.v9n4p319
Accepted: November 6, 2014 Online Published: March 30, 2015

URL: http://dx.doi.org/10.5539/mas.v9n4p319

\begin{abstract}
Syntactic foams are of interest to solve the problem of increase in the efficiency of heat supply equipment and pipelines heat insulation. The article analyses the efficiency of the use of various microspheres for syntactic foams when used for heat supply equipment and pipelines heat insulation. Moscow Power Engineering Institute has been conducting a large number of researches with the use of specific universal methods and the test stand which meets the modern requirements in order to determine the heat conductivity coefficient of various heat-insulating materials. These studies are designed to identify the impact of binding materials and microspheres properties over syntactic foams heat conductivity. The results of researches show that microspheres properties impact the heat-insulating characteristics of coatings.
\end{abstract}

Keywords: microspheres, heat supply, heat insulation, heat networks, heat-insulating materials, heat conductivity coefficient, syntactic foams

\section{Introduction}

Specialists are of the opinion that practically all modern traditional heat-insulating materials are apt to quick ageing and destruction; their actual operating life is maximum ten years (Ivanov et al., 2010). So there is an objective need to search for and use new heat-insulating materials.

In order to solve the problem of increase in the efficiency of heat supply equipment and pipelines heat insulation, heat-insulating materials obtained with the use of hollow microspheres and various binding agents - the so-called syntactic foams - are of utmost interest (John \& Reghunadhan, 2014).

In syntactic foam specifications and manuals the heat conductivity coefficient ranges from 0.001 to 0.450 $\mathrm{W} / \mathrm{m} \cdot \mathrm{K}$. Therefore there is an issue of efficiency of the use of a certain microsphere type as a part of syntactic foams for heat supply equipment and pipelines heat insulation.

It is well-known that the key parameter influencing efficiency of the use of a certain heat-insulating material is its heat conductivity coefficient (ISO 10456, 2007). Moscow Power Engineering Institute has conducted a large number of researches with the use of specific universal method and the test stand which meets the modern requirements in order to determine the heat conductivity coefficient of various heat-insulating materials. These researches were designed to determine the impact of binding materials and microspheres characteristics over syntactic foam heat conductivity. The results of researches show that microspheres properties (size, concentration in syntactic foams, presence/ absence of a gaseous phase inside microspheres) have major impact over the heat-insulating characteristics of coatings (Ryzhenkov et al., 2010).

\section{Heat-Insulating Materials Classification}

All natural and artificial heat-insulating materials (HM) may be divided into several groups given in Table 1 . Also Table 1 contains the most common representatives of a respective group. 
Table 1. Heat-insulating materials classification

\begin{tabular}{|c|c|c|c|c|}
\hline \multirow[t]{2}{*}{ Formation type } & \multicolumn{4}{|c|}{ Types } \\
\hline & non-organic & organic & & combined \\
\hline fibre & $\begin{array}{l}\text {-asbestos } \\
\text {-mineral cotton } \\
\text { - glass wool } \\
\text { - fibreglass }\end{array}$ & $\begin{array}{l}\text { - felt } \\
\text {-wood } \\
\text {-flax } \\
\text {-cotton } \\
\text { - cane fibre boards }\end{array}$ & & - \\
\hline porous & $\begin{array}{l}\text {-expanded perlite } \\
\text {-vermiculite } \\
\text {-foamed concrete } \\
\text {-gas concrete }\end{array}$ & $\begin{array}{l}\text {-cork } \\
\text { - polystyrene foam } \\
\text { - polyurethane foam } \\
\text {-foamed rubbers }\end{array}$ & & -foamed resin concrete \\
\hline composite & $\begin{array}{l}\text {-cement-based syntactic } \\
\text { foams (light concrete) } \\
\text {-fibre-reinforced cement }\end{array}$ & $\begin{array}{l}\text {-polymer } \\
\text { microsphere-based } \\
\text { syntactic } \\
\text { (spheroplasts) }\end{array}$ & foams & $\begin{array}{l}\text {-syntactic foams based on } \\
\text { polyurethane, epoxy resins, } \\
\text { acryl latex, rubber, silicon } \\
\text { emulsions }\end{array}$ \\
\hline
\end{tabular}

Heat-insulating materials efficiency in a heat-insulating structure as regards power pipelines and equipment is primarily dependant on their physical and mechanical properties, the main of which are as follows (Kopko, 2002): heat conductivity coefficient, temperature limit of application, moisture absorption, density, static limits of compressive, bending and tensile strength.

The main property influencing the material use efficiency in terms of heat insulation is the lowest heat conductivity coefficient.

The most important parameter for heat-insulating structures used for power pipelines and equipment is also the limit operating temperature.

For power pipelines and equipment installed in the living area or in production shops, HMs with low heat conductivity and high heat stability are used. Usually such materials are characterized by low special density, making them more hygroscopic and water absorbent.

In a number of cases e.g. for underground heat supply pipelines apt to watering with ground waters, a HM should have low water absorption factor.

It is well-known that insulating material heat conductivity with the special density of $20 \%$ is 3 higher than that of a dry insulating material (Sokolov, 1999). In addition, presence of water in a heat-insulating material contacting equipment promotes intensive corrosion of a majority of structural equipment materials.

Recently organic polymer coatings have been gaining wider application. Polymer heat-insulating materials are made of thermosetting and thermoplastic resins, expanding agents, hardening agents and additives that improve materials' operating characteristics. Depending on the porosity type, porous heat-insulating materials are divided into cellular, or foamed (foam plastics) and porous (porous foams). Polymers obtained as a result of the original plastic foaming look like set foam. Foam plastics cells are filled with air or gas and are not connected (closed structure), whereas porous foams cells are connected (open structure). Presence of gas-filled pores, which are known to possess the lowest heat conductivity coefficient, gives organic polymers high heat-shielding properties and makes them quite perspective for large-scale use for power equipment and pipelines protection, e.g. heat networks. But polymer coatings have one peculiarity, greatly limiting efficiency of their use in heat supply systems: the higher the heat-shielding coefficient is, the lower the heat stability is.

Depending on the density, the heat conductivity of a heat-insulating material (and its functionality) changes a lot. Thus heat-insulating materials are materials with the density of less than $500 \mathrm{~kg} / \mathrm{m}^{3}$, constructive heat-insulating materials have the density of $500-1000 \mathrm{~kg} / \mathrm{m}^{3}$, and constructive materials' density is $1000-1200 \mathrm{~kg} / \mathrm{m}^{3}$.

The key physical and chemical properties of heat-insulating materials traditionally used for power equipment and pipeline insulation are given in Table 2 (Kochergin, 2008; Mikulskiy and Kozlova 2004). To analyse all modern materials within the scope of this article is very hard because of their abundance and diversity.

Table 2 demonstrates that despite the low heat conductivity coefficient of such materials as mineral wool, foamed mineral polymer, reinforced foam concrete, they are inefficient due to high water absorption. Materials such as foamed rubber, phenol-resol porous plastics, polyurethane foam and foamed polymer concrete have a 
relatively low heat resistance.

Table 2. Key properties of heat-insulating materials, most commonly used for power equipment and pipeline insulation

\begin{tabular}{|c|c|c|c|c|c|}
\hline Description & $\begin{array}{l}\text { Density (apparent } \\
\text { density), } \mathrm{kg} / \mathrm{m}^{3}\end{array}$ & $\begin{array}{l}\text { Heat conductivity } \\
\text { coefficient, } W /(\mathbf{m} \cdot \mathbf{K})\end{array}$ & $\begin{array}{l}\text { Water } \\
\text { absorp } \\
\text { tion } \\
\text { during } \\
24 \\
\text { hours }\end{array}$ & $\begin{array}{l}\text { Compressive } \\
\text { strength, MPa }\end{array}$ & $\begin{array}{l}\text { Temperat } \\
\text { ure } \\
\text { limit of } \\
\text { applicati } \\
\text { on, }{ }^{\circ} \mathrm{C}\end{array}$ \\
\hline 1 & 2 & 3 & 4 & 5 & 6 \\
\hline Mineral wools & $34 \div 500$ & $0.033 \div 0.058$ & $\begin{array}{l}3 \% \\
\text { volume }\end{array}$ & $0.001 \div 0.015$ & 700 \\
\hline \multicolumn{6}{|l|}{ Glass cotton and fibre glass } \\
\hline & $13 \div 140$ & $0.010 \div 0.045$ & - & $0.030 \div 0.061$ & 400 \\
\hline $\begin{array}{l}\text { Foamed polymer concrete (foamed } \\
\text { mineral polymer) }\end{array}$ & 400 & 0.07 & $\begin{array}{l}5 \% \\
\text { volume }\end{array}$ & 0.8 & 150 \\
\hline Polyurethane foam (PU foam) & $50 \div 100$ & $0.033 \div 0.05$ & $\begin{array}{l}0.8 \% \\
\text { volume }\end{array}$ & $0.1 \div 0.22$ & 130 \\
\hline Phenol-resol porous plastics (PRP) & $65 \div 110$ & $0.041 \div 0.043$ & - & $0.4 \div 3.0$ & 150 \\
\hline Reinforced foam concrete & $350 \div 450$ & $0.08 \div 0.16$ & $\begin{array}{l}14 \% \\
\text { weight }\end{array}$ & $1.0 \div 2.5$ & 300 \\
\hline Foamed rubber & $35 \div 150$ & $0.038 \div 0.047$ & $\begin{array}{l}<3.3 \% \\
\text { volume }\end{array}$ & - & 150 \\
\hline
\end{tabular}

\section{Syntactic Foams}

Syntactic foams are a type of gas-filled composite polymer materials (PCM), where the filling agents are hollow spherical particles evenly distributed in the binding agent. Cells in such foams are formed not as a result of polymer foaming, but due to introduction of hollow microspheres (Volkov and Zuev 2008). Microsphere presence makes the material a close-grained one.

Microspheres introduction into a composite material (CM) results in reduction of material density, compaction and heat conductivity. It has been proven that microspheres concentration and size as well as gaseous phase composition pose determining influence over the thermophysical properties of syntactic foams (Li et al., 2011; Loginova, 2010; Liao 2011). Binding agents in syntactic foams ensure mechanical strength and heat stability of a heat-insulating coating and additional anticorrosion activity when used on a base metal surface (Loginova, 2010).

\section{Microspheres}

For syntactic foams, aluminosilicate, glass and polymer microspheres are usually used.

Aluminosilicate microspheres, which are also called ash and ceramic ones, result from grained coal particles combustion. Admixtures of aluminium oxide, silicon and other elements present in natural coal form complex silicates under high temperatures. Presence of molten silicate gases leads to fusion microdroplets inflation into small hollow spherical particles - ash microspheres (Purkhalo et al., 2009). They look like hollow aluminosilicate balls, their average size being 10-500 $\mu \mathrm{m}$, with the following chemical elements present in their membrane: $\mathrm{SiO}_{2}-55-65 \% ; \mathrm{Al}_{2} \mathrm{O}_{3}-25-33 \% ; \mathrm{Fe}_{2} \mathrm{O}_{3}-1-6 \% ; \mathrm{CaO}-0.2-0.6 \% ; \mathrm{MgO}-1-2 \% ; \mathrm{K}_{2} \mathrm{O}-0.2-4 \%$; $\mathrm{Na}_{2} \mathrm{O}-0.3-2 \%$; $\mathrm{TiO}_{2}-0.5-1 \%$. The main components of the microsphere phase-mineral composition are aluminosilicate glass phase, mullite, quartz. Some alloys may include red iron ore, feldspar, black iron ore, hydromica, and calcium lime (Cherepanov \& Kardysh, 2009).

Microspheres may be thin-walled with the specific weight of $0.4-0.7 \mathrm{~g} / \mathrm{cm}^{3}$ and thick-walled with the specific 
weight of $2-2.2 \mathrm{~g} / \mathrm{cm}^{3}$. The thin-walled microsphere disadvantage is its brittleness and low strength. The thick-walled microsphere membrane thickness is $10 \%$ of its diameter making it stronger. Besides thick walls ensure erosion resistance and impenetrability by liquids and gases, but at the same time thick walls reduce the gas phase volume inside a microsphere thus reducing efficiency of their use in heat-insulating materials (Purkhalo et al., 2009).

The gaseous phase inside ash microsphere consists of carbon dioxide $\left(\mathrm{CO}_{2}\right)-70 \%$ and nitrogen $\left(\mathrm{N}_{2}\right)-30 \%$.

It has been proven that use of syntactic foams with aluminosilicate microspheres is not efficient in high-temperature objects insulation (Loginova, 2010).

Glass microspheres may be both solid and hollow.

Solid balls are obtained either by broken glass baking with follow-up spherical product collection and cooling, or by melting of a glass portion with follow-up free-falling fusion flow breaking, resulting in small droplets (Katz \& Milewski, 1978).

Hollow glass balls are obtained by heating of broken glass containing a foamed agent. During condensation the interfacial tension results in spherical shape of particles. The gas originating under the foamed agent influence expands and forms hollow spheres (Kantos, 2010).

At the Russian glass microspheres market, the most common are microspheres made of sodium-borosilicate glass with the following composition: $\mathrm{SiO}_{2}-71.7-73.8 \% ; \mathrm{Na}_{2} \mathrm{O}-25.5-28.2 \% ; \mathrm{B}_{2} \mathrm{O}-3.8-4.4 \% ; \mathrm{Al}_{2} \mathrm{O}_{3}+\mathrm{Fe}_{2} \mathrm{O}_{3}-$ max. 0.4\% (TOR 6-48-91-92).

Such microspheres are obtained under the method based on passing of dry sodium-borosilicate glass solution through flame. The method is as follows: potassium silicate, sodium silicate or their mix are pre-dissolved in water using a steam chamber. The resulting solution is mixed with the mix of boric acid and urea and is fed into the spray drier, where frits are obtained under the flush movement of the sprayed material in the igniting heating medium stream. Ready frits are transported into vertical pipe furnaces, where hollow microspheres are formed in an ascending gas stream. Depending on the glass designation (heat resistant, heat stable, radiation resistant, optic, etc.), other compositions are used for frit production (Ryzhenkov et al., 2012).

The gaseous medium inside hollow glass microspheres contains carbon dioxide $\left(\mathrm{CO}_{2}\right), 322$ ulphur dioxide $\left(\mathrm{SO}_{2}\right)$, oxygen $\left(\mathrm{O}_{2}\right)$ and other gases depending in the chemical composition of glass.

In addition, de-aerated microspheres may be obtained by placing an ultrasound vibrator into the vacuum chamber, and the glass fusion unit is installed above it. In vacuum, a molten glass drop is spayed on the vibrator under the normal pressure. The vibrator divides the drop into a number of smaller droplets which, once in vacuum, become spherical and cool down at the temperature below the melting point. It results in practically ideal spheres with the internal pressure meeting the vacuum chamber pressure. The resulting microsphere size may be regulated with the ultrasound vibrator frequency (Tychenkov, 2010).

The specific weight of solid microspheres is at least $2.4 \mathrm{~g} / \mathrm{cm}^{3}$, their size is $15-850 \mu \mathrm{m}$. The specific weight of hollow microspheres is $0.05-0.4 \mathrm{~g} / \mathrm{cm}^{3}$, their size is $15-500 \mu \mathrm{m}$.

In order to obtain hollow glass microspheres with porous walls, glass powder with $20-40 \mu \mathrm{m}$ particles is placed into the furnace where the glass softens at high temperature, and particles become spherical. Glass contains a foaming agent which decomposes at a certain temperature and forms bubbles. Then the glass is hardened in a water stream resulting in glass microspheres formation. Sphere walls are stained with chlorhydric acid to make them porous (Technical presentation of Expancel microspheres, 2011). Open porosity leads to these microspheres being filled with air.

There are also polymer microspheres. One sub-class of polymer microspheres is thermoplastic polymer microspheres. Their distinctive feature is a thermoplastic polymer membrane which allows a polymer microsphere changing its volume once the temperature changes: when heated, the gaseous medium volume grows, the polymer membrane becomes softer, and microspheres volume increases greatly. Propellant-encapsulating polymer membrane is a polymer based on ethylene hydrocarbons. The propellant is a hydrocarbon or a mix of hydrocarbons where the boiling point does not exceed the softening temperature of the thermoplastic polymer membrane. When heated, the propellant evaporates, and the internal pressure grows once the membrane softens resulting in considerable microspheres expansion. Thus, the gaseous medium inside microspheres is a hydrocarbon, and the gas inside microspheres determined the inside pressure at a given temperature (Technical presentation of Expancel microspheres, 2012; Nordin et al., 2011).

Polymer membrane microspheres may be both unexpanded (expandable) and expanded (pre-expanded). 
Expandable microspheres may be obtained by monomer polymerization with ethylene subtility where propellant is present. Their diameter is 1-500 $\mu \mathrm{m}$. Expanded microspheres are easy to compress, and once the pressure reduces, their initial volume recovers. They also have low gas permeability.

In order to obtain pre-expanded microspheres, they are heated to the temperature, above which expansion begins. The upper temperature limit is the moment when microspheres start to disintegrate and it depends on a certain composition of the polymer membrane and propellant (Nordin et al., 2011).

Pre-expanded microspheres are used in processes, where no heat is emitted or heat emitted is not enough to ensure microspheres expansion (Technical presentation of Expancel microspheres, 2012).

There are a lot of other polymer microspheres e.g. polystyrene, silicone, phenol-formaldehyde microspheres, etc. The methods for their obtaining are various: radical polymerization, thermal processing of sprayed solutions or emulsions with the use of various polymerization processes and dispersion, by gradual growth of microspheres obtained at the initial synthesis stage, etc. Polymer microspheres may be used instead of glass microspheres in order to reduce the material density.

Polymer microspheres disadvantages include low thermal stability $\left(\max .90^{\circ} \mathrm{C}\right)$ and low durability which considerably limit the possibility of their use as a filling agent in heat-insulating coatings for protection of pipelines, power equipment and other industrial process equipment operated at high temperatures.

The key microspheres characteristics are given in Table 3.

Table 3. Key microspheres characteristics

\begin{tabular}{|c|c|c|c|c|c|c|}
\hline Item & $\begin{array}{l}\text { Microsphere } \\
\text { type }\end{array}$ & Origin & $\begin{array}{l}\text { Microsphere } \\
\text { composition }\end{array}$ & $\begin{array}{l}\text { Gaseous } \\
\text { medium } \\
\text { composition }\end{array}$ & Size, $\mu \mathrm{m}$ & $\begin{array}{l}\text { Thermal } \\
\text { stability, }{ }^{\circ} \mathrm{C}\end{array}$ \\
\hline 1 & Aluminosilicate & $\begin{array}{l}\text { high-temperature } \\
\text { coal flaring }\end{array}$ & $\begin{array}{l}\mathrm{SiO} 2-55-65 \% ; \mathrm{Al} 2 \mathrm{O} 3 \\
-25-33 \% ; \mathrm{Fe} 2 \mathrm{O} 3- \\
1-6 \% ; \mathrm{CaO}-0.2-0.6 \% \\
\mathrm{MgO}-1-2 \% ; \mathrm{K} 2 \mathrm{O}- \\
0.2-4 \% ; \mathrm{Na} 2 \mathrm{O}- \\
0.3-2 \% \text {; } \mathrm{TiO} 2-0.5-1 \% \\
\text { (Purkhalo et al., 2009). }\end{array}$ & $\begin{array}{l}\mathrm{CO}_{2}-70 \% \\
\mathrm{~N}_{2}-30 \%\end{array}$ & $20-500$ & $\begin{array}{l}\text { 1,400-1,500 } \\
\text { (Purkhalo et } \\
\text { al., 2009) }\end{array}$ \\
\hline 2 & Solid glass & $\begin{array}{l}\text { from fusions in } \\
\text { vertical pipe furnace }\end{array}$ & $\begin{array}{l}\mathrm{SiO}_{2}-71.7-73.8 \% \\
\mathrm{Na}_{2} \mathrm{O}-25.5-28.2 \% \\
\mathrm{~B}_{2} \mathrm{O}-3.8-4.4 \% ; \mathrm{Al}_{2} \mathrm{O}_{3} \\
+\mathrm{Fe}_{2} \mathrm{O}_{3}-\max 0.4 \% \\
\text { (TOR 6-48-91-92) }\end{array}$ & - & $15-850$ & $\begin{array}{l}700 \text { (Kantos, } \\
\text { 2010) }\end{array}$ \\
\hline 3 & $\begin{array}{l}\text { Hollow glass } \\
\text { (gas filled) }\end{array}$ & $\begin{array}{l}\text { from fusions in } \\
\text { vertical pipe furnace }\end{array}$ & $\begin{array}{l}\mathrm{SiO}_{2}-71.7-73.8 \% \\
\mathrm{Na}_{2} \mathrm{O}-25.5-28.2 \% \\
\mathrm{~B}_{2} \mathrm{O}-3.8-4.4 \% ; \mathrm{Al}_{2} \mathrm{O}_{3} \\
+\mathrm{Fe}_{2} \mathrm{O}_{3}-\max .0 .4 \% \\
\text { (TOR 6-48-91-92). }\end{array}$ & $\begin{array}{l}\mathrm{CO}_{2} \\
\mathrm{SO}_{2} \\
\mathrm{O}_{2} \text { and other }\end{array}$ & $15-500$ & $\begin{array}{l}700 \text { (Kantos, } \\
\text { 2010) }\end{array}$ \\
\hline 4 & $\begin{array}{l}\text { Hollow glass } \\
\text { (de-aerated) }\end{array}$ & $\begin{array}{l}\text { from fusions with } \\
\text { the use of a vacuum } \\
\text { chamber and } \\
\text { ultrasound vibrator }\end{array}$ & $\begin{array}{l}\mathrm{SiO}_{2}-71.7-73.8 \% \\
\mathrm{Na}_{2} \mathrm{O}-25.5-28.2 \% \\
\mathrm{~B}_{2} \mathrm{O}-3.8-4.4 \% ; \mathrm{Al}_{2} \mathrm{O}_{3} \\
+\mathrm{Fe}_{2} \mathrm{O}_{3}-\max .0 .4 \% \\
\text { (TOR 6-48-91-92). }\end{array}$ & $\begin{array}{l}\text { A mix of gases } \\
\left(\mathrm{CO}_{2}, \mathrm{SO}_{2}, \mathrm{O}_{2},\right. \\
\text { etc. }) \text { in the } \\
\text { vacuum state }\end{array}$ & $15-500$ & $\begin{array}{l}700 \text { (Kantos, } \\
\text { 2010) }\end{array}$ \\
\hline 5 & $\begin{array}{l}\text { Hollow glass } \\
\text { microsphere } \\
\text { with porous } \\
\text { walls }\end{array}$ & $\begin{array}{l}\text { microspheres walls } \\
\text { staining with } \\
\text { chlorhydric acid }\end{array}$ & $\begin{array}{l}\mathrm{SiO}_{2}-71.7-73.8 \% \\
\mathrm{Na}_{2} \mathrm{O}-25.5-28.2 \% \\
\mathrm{~B}_{2} \mathrm{O}-3.8-4.4 \% ; \mathrm{Al}_{2} \mathrm{O}_{3} \\
+\mathrm{Fe}_{2} \mathrm{O}_{3}-\max .0 .4 \% \\
\text { (TOR 6-48-91-92). }\end{array}$ & $\begin{array}{l}\mathrm{N}_{2}-78.03 \% ; \\
\mathrm{O}_{2}-20.95 \% ; \\
\mathrm{CO}_{2}-0.07 \% \\
\text { etc. }\end{array}$ & $2-100$ & $\begin{array}{l}700 \text { (Kantos, } \\
\text { 2010) }\end{array}$ \\
\hline 6 & $\begin{array}{l}\text { Polymer } \\
\text { thermoplastic } \\
\text { unexpanded }\end{array}$ & $\begin{array}{l}\text { monomer } \\
\text { polymerization with } \\
\text { ethylene subtility }\end{array}$ & $\begin{array}{l}\text { monomers with } \\
\text { ethylene subtility }\end{array}$ & $\mathrm{C}_{\mathrm{n}} \mathrm{H}_{\mathrm{m}}$ & $1-500$ & $\begin{array}{l}90 \text { (Nordin et } \\
\text { al., 2011) }\end{array}$ \\
\hline
\end{tabular}




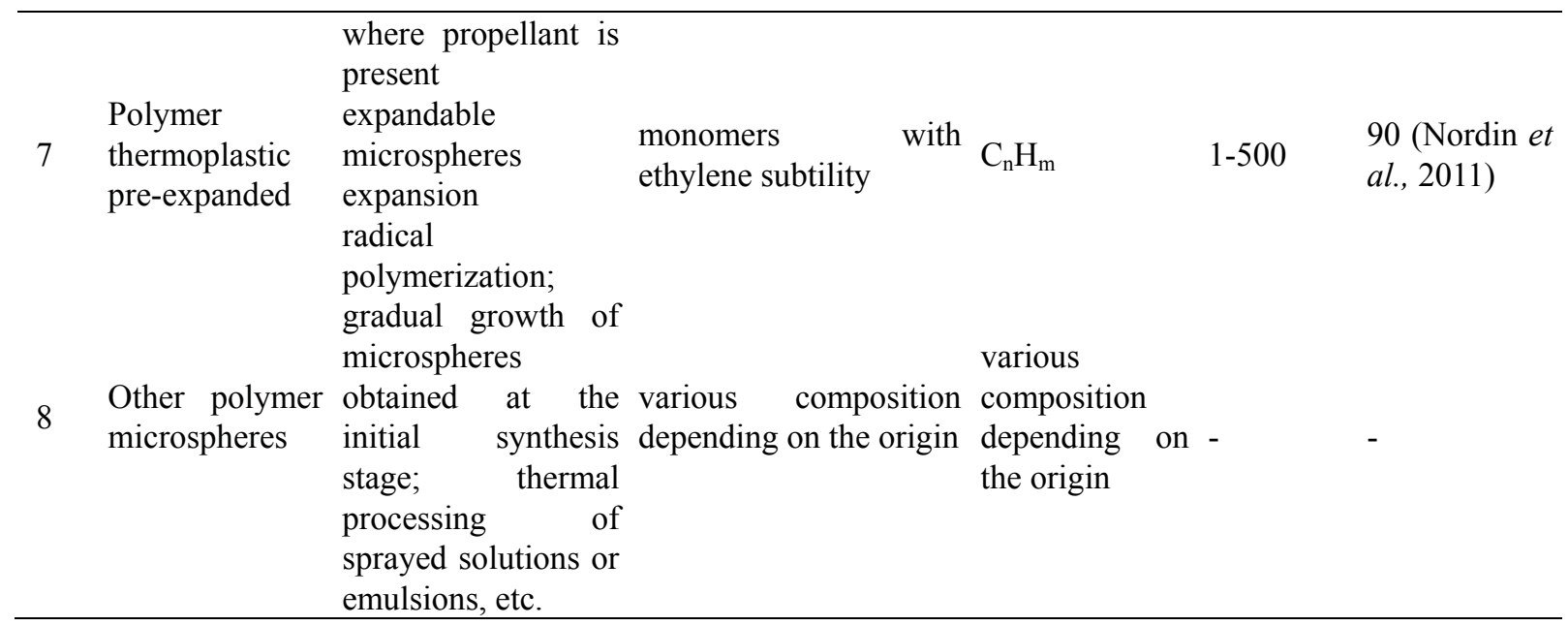

Microspheres cannot form other adhesion contacts, therefore when materials are produced on their basis, several approaches are considered (Kersh and Kolesnikov, 2013): 1) microsphere surface pre-treatment with surface-active adhesive additives, 2) use of a mineral or polymer binding agent. Literary sources also describe joint approaches to HM creation (Varlamova et al., 2011; Varlamova, 2013; Ryutkyanen et al., 2012). In (Varlamova et al., 2011) aluminosilicate microspheres were pre-treated with copolymers of (met)acroleic acid derivatives in order to ensure the filling material affinity with the polymer matrix. Such microspheres surface modification results in increase in strength characteristics of the resulting heat-insulating material. It is worth mentioning that microspheres surface may be coated with fire-retarding agents in order to reduce composition flammability (Donskoy and Baritko, 2006).

The most widely discussed is HM formation on the basis of microspheres without additionally treated surface. The amount and quality of microspheres introduced impacts the heat-insulating properties of a material, and also there are by-effects: growth in viscosity and system strength appearance or growth. The majority of filled systems studied demonstrate the critical filling level, above which there is a sharp change in phonological parameters and strength values (Varlamova et al., 2011).

\section{About Syntactic Foam Studies}

In order to solve the issue of syntactic foam efficiency for heat supply systems and power equipment, Moscow Power Engineering Institute conducted a number of researches to identify the impact of various microspheres over thermophysical properties.

The analysis of the patent base showed that in the majority of cases syntactic foams are based on aluminosilicate, gas- or carbon dioxide-filled microspheres obtained from ashes, and microspheres obtained under industrial methods from glass fusion with rarefied air inside.

In this view, these microspheres were used for syntactic foams researches. The researches were focused on the temperature distribution on the syntactic foam film surface of a cylindrical sample. The set temperatures within the range of $+50^{\circ} \mathrm{C}-+120^{\circ} \mathrm{C}$ on the initial sample surface were maintained with a heater; the temperatures were regulated by an electronic controller. The mentioned temperature range is typical of heat supply systems.

Then, the calculation connection (1) for a cylindrical wall obtained from Fourier heat conductivity equation was used to determine the heat conductivity (Tsvetkov and Grigoriev, 2001):

$$
\lambda=\frac{q r_{1} l \frac{r_{2}}{r_{1}}}{T_{1}-T_{2}}
$$

where $r_{1}, r_{2}$ are radii at the outer surface of an initial cylindrical sample and at the outer surface of a syntactic foam surface, respectively, $\mathrm{m}$;

$q$ is the heat stream density, $\mathrm{W} / \mathrm{m}^{2}$;

$\mathrm{T}_{1}, \mathrm{~T}_{2}$ are the temperature at the outer surface of an initial cylindrical sample and at the outer surface of a syntactic foam surface, $\mathrm{K}$.

In particular, the heat conductivity coefficient of a one-layer syntactic foam coating was $0.022 \mathrm{~W} / \mathrm{m} \cdot \mathrm{K}$ at $60^{\circ} \mathrm{C}$ and $0.030 \mathrm{~W} / \mathrm{m} \cdot \mathrm{K}$ at $100^{\circ} \mathrm{C}$ for microsphere coating with rarefied air, and $0.14 \mathrm{~W} / \mathrm{m} \cdot \mathrm{K}$ and $0.18 \mathrm{~W} / \mathrm{m} \cdot \mathrm{K}$ for 
coatings with gas-filled microspheres under the similar conditions. The results shown in Figure1 demonstrate that the heat conductivity coefficient of syntactic foams when gas-filled microspheres are used, as compared to rarefied air-filled microspheres, is much higher.

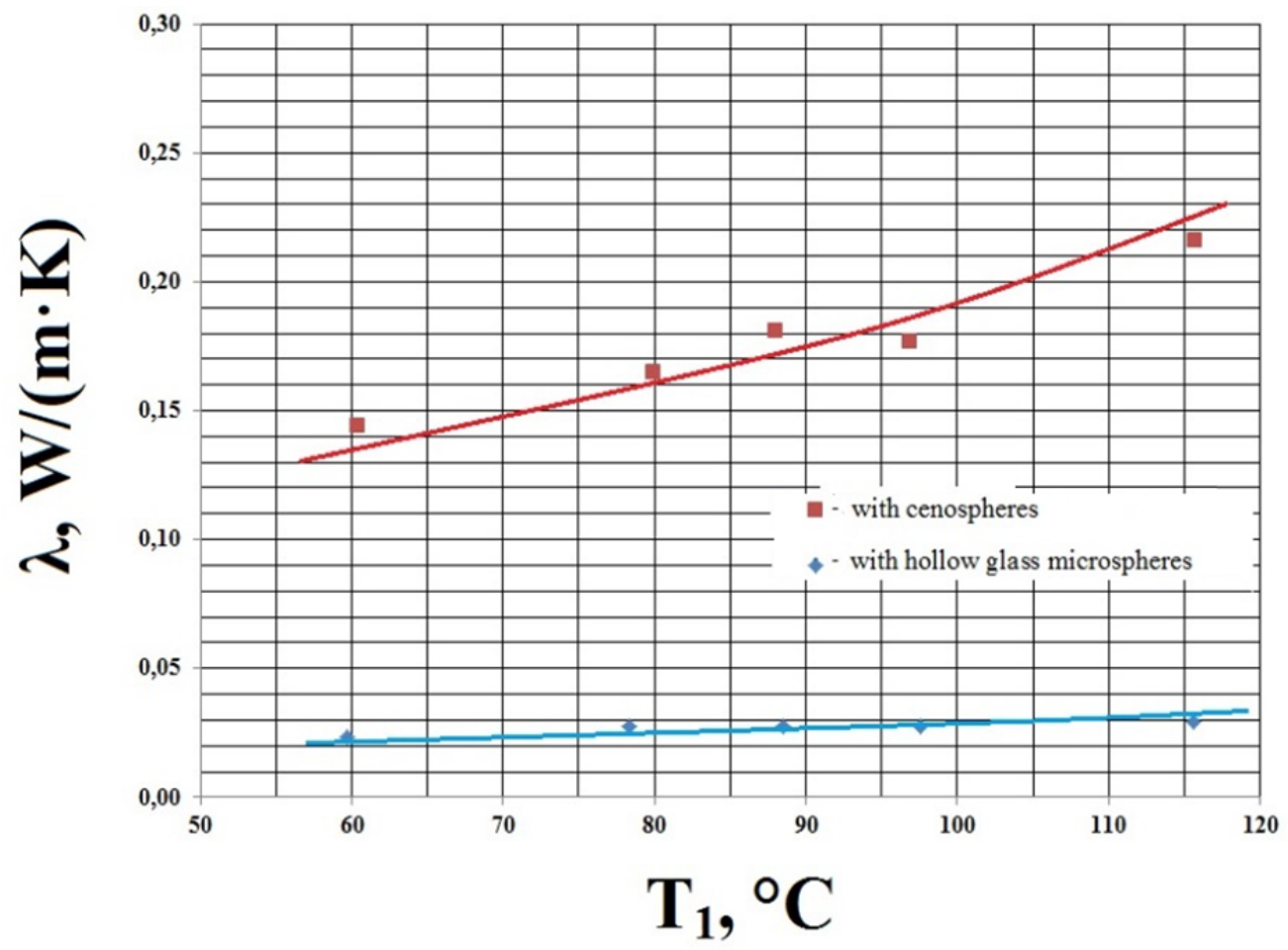

Figure 1. Temperature impact over the heat conductivity coefficient of syntactic foams when de-aerated and gas-filled microspheres are used

\section{Discussion}

Use of microspheres in syntactic foams influences their heat-insulating properties, ensures material density and heat conductivity reduction. Use of thick-wall microspheres in syntactic foams ensures their high erosion resistance and impenetrability by liquids and gases, but at the same time thick walls reduce the gas phase volume inside a microsphere thus reducing efficiency of their use in heat-insulating materials. In a number of cases, where syntactic foams are designed for the operating temperatures below $90^{\circ} \mathrm{C}$, it is advisable to replace glass and aluminosilicate microsphere with polymer ones in order to reduce material density. High-efficiency heat-insulating materials creation and production as regards heat supply systems is possible only with the use of microspheres with rarefied air inside.

\section{Conclusion}

Low thermal stability $\left(\max .90^{\circ} \mathrm{C}\right)$ of the polymer microspheres is limiting their use as a filling agent in heat-insulating coatings for protection of pipelines, power equipment and other industrial process equipment operated at high temperatures. The heat conductivity coefficient of a one-layer syntactic foam coating on the basis of hollow glass microspheres with rarefied air inside is an order of magnitude more than for coatings with gas-filled microspheres under the similar conditions.

The results demonstrated the efficiency of syntactic foams on the basis of hollow glass microspheres with rarefied air inside, both to reduce heat losses from pipe surface and to protect personnel from burns from heat surface contacting. All these facts make syntactic foams very perspective, but requires additional researches.

\section{Acknowledgement}

The work was undertaken with the financial aid by the Ministry of Education and Science of the Russian Federation under Agreement No.14.574.21.0069 dated June 27, 2014 "Development of a flexible, economical, quickly erected heat-insulating structure in order to increase the heat exchange equipment and pipes efficiency" 
(unique identification number RFMEFI57414X0069).

\section{References}

Cherepanov, A., \& Kardysh, V. (2009). Complex processing of TPP ashes (lab and semi-industrial test results). Geology and Mineral Resources of the World Ocean, 2, 98-115.

Donskoy, A. A., \& Baritko, N. V. (2006). Self-extinguishing low-density joint fillers. Glues. Joint fillers. Technologies, 9, 1-10.

ISO 10456. (2007). Building Materials and Products-tabulated Design Values and Procedures for Determining Declared and Design Thermal Values. International Organization for Standardisation, Geneva.

Ivanov, V. V., Bukarov, N. V., \& Vasilenko, V. V. (2010). Impact of insulation and ground moistening over heat losses in subsurface heat traces. Electronic magazine "Energosovet", 7(12).

John, B., \& Reghunadhan Nair, C. P. (2014). Handbook of Thermoset Plastics. Handbook of Thermoset Plastics (pp. 511-554), http://dx.doi.org/10.1016/B978-1-4557-3107-7.00013-0

Kantos, M. (2010). Functional filling agents for plastics. St. Petersburg, St. P.: Scientific fundamentals and technologies.

Katz, H. S., \& Milewski, J. V. (1978). Handbook of fillers and reinforcements for plastics. New York, NY: Van Nostrand Reinhold Co.

Kersh, V. Ya., \& Kolesnikov, A. V. (2013). Optimization of interaction between particles in a complex heat-insulating material. Bulletin Incercon, 4, 53-63.

Kochergin, S. M. (2008). Heat insulation. Materials, structures, technologies: Reference Book. Moscow, M.: Stroyinfrom.

Kopko, V. M. (2002). Heat network pipe heat insulation: Study Guide. Minsk, M: Tehnoprint.

Li, B., Yuana, Y., An, Z., \& Zhang, J. (2011). Effect of microstructure and physical parameters of hollow glass microsphere on insulation performance. Material Letters, 65(12), 1992-1994, http://dx.doi.org/10.1016/j.matlet.2011.03.062

Liao, Y., Wua, X., Liua, H., \& Chen, Y. (2011). Thermal conductivity of powder silica hollow spheres. Thermochimica Acta, 526, 178-184. http://dx.doi.org/10.1016/j.tca.2011.09.011

Loginova, N. A. (2010). Determination of thin-film thermal insulation coatings efficiency in heat supply systems. (Master's theses, National Research University "Moscow Power Engineering Institute", Moscow).

Mikulskiy, V. G., \& Kozlov, V. V. (2004). Construction materials. Moscow, M.: Construction Institutes Association.

Nordin, O., Strem, Kh., Nuholm, K., \& Khammer, K. (2011). Microspheres: patent RU 2432201 C2; application: 2008136397/05, 12.01.2007; published 27.10.2011, Bull. 30.

Pavlushkin, N. TOR 6-48-91-92. Glass and glass articles.

Purkhalo, Yu., Areshkin, V., \& Kulnitskiy, A. (2009). Silicate microsphere. Application perspectives. Corrosion. Oil and gas area, 2, 52-54.

Ryutkyanen, E. A., Sirotinkin, N. V., \& Uspenskaya, M. V. (2012). Filling agent surface modification impact over latex films properties. Scientific and engineering bulletin of IT, mechanics and optics, 6(82), 106-110.

Ryzhenkov, V., Prischepov, A., \& Loginova, N. (2012). Thin-film insulation materials efficiency. Power Engineering Reliability and Safety, 2(17), 61-63.

Ryzhenkov, V. A., Prischepov, A. F., \& Loginova, N. A. (2010). Impact of microspheres and binding agent characteristics over the heat conductivity of thin-film heat-insulating coatings. Power Engineering Reliability and Safety, 3(10), 28-30.

Sokolov, E. Ya. (1999). District heating and heat networks: Study Guide for higher education establishments. Moscow, M.: Moscow Power Engineering Institute' publishing house.

Technical presentation of Expancel microspheres (2011). http://dx.doi.org/10.1016/S0969-6210(11)70101-1

Tsvetkov, F. F., \& Grigoriev, B. A. (2011). Heat and weight exchange: Study Guide for higher education establishments. Moscow, M.: Moscow Power Engineering Institute' publishing house.

Tychenkov, E., \& Vakulenko, Yu. (2010). Composition for a heat-insulating coating and application method: 
patent $013735 \mathrm{EA}$; published in 2010.

Varlamova, L. P. (2013). Composite urethane foam materials filled with intercalated graphite and aluminosilicate ash microspheres (Master's theses). Federal State Institution of Science Institute

Varlamova, L. P., Varyukhin, V. A., Domrachev, G. A., Drozhzhin, V. S., Egorov, V. A., Izvozchikova, V. A., ... Semenov, N. M. (2011). Het-insulating composition: patent RU 2414495 C1; application: 2009125209/05, 01.07.2009; published 20.03.2011, Bull. 8.

Volkov, G. M., \& Zuev, V. M. (2008). Material science. Moscow, M.: Academy Publishing House.

\section{Copyrights}

Copyright for this article is retained by the author(s), with first publication rights granted to the journal.

This is an open-access article distributed under the terms and conditions of the Creative Commons Attribution license (http://creativecommons.org/licenses/by/3.0/). 